\title{
TALL-HERB BOREAL FORESTS ON NORTH URAL
}

\author{
A. A. Aleinikov \\ Center for Problems of Ecology and Productivity of Forests, Russian Academy of Sciences (RAS), \\ 84/32 Profsoyuznaya street, Moscow, 117997, Russia \\ E-mail:aaacastor@gmail.com
}

\section{N. S. Smirnov}

Institute of Global Climate and Ecology of Roshydromet and Russian Academy of Sciences (RAS), 20B Glebovskaya street, Moscow, 107258, Russia;

Pechora-llych State Nature Reserve, 8 Lanina street, Yaksha, Komi Republic, 169436, Russia

E-mail: smns-80@rambler.ru

\section{O. V. Smirnova}

Center for Problems of Ecology and Productivity of Forest, Russian Academy of Sciences (RAS),

84/32 Profsoyuznaya street, Moscow, 117997, Russia

E-mail: ovsinfo@gmail.com

\section{ВЫСОКОТРАВНЫЕ ЛЕСА СЕВЕРНОГО УРАЛА}

\section{А. А. Алейников}

Центр по проблемам экологии и продуктивности лесов РАН, Россия, 117997, г. Москва, ул. Профсоюзная, 84/32 E-mail: aaacastor@gmail.com

\section{Н. С. Смирнов}

Институт глобального климата и экологии Росгидромета и РАН, Россия, 107258, г. Москва, ул. Глебовская, 20Б; Печоро-Илычский государственный природный заповедник, Россия, 169436, Республика Коми, пст. Якща, ул. Ланиной, 8 E-mail:smns-8o@rambler.ru

\section{О. В. Смирнова}

Центр по проблемам экологии и продуктивности лесов РАН, Россия, 117997, г. Москва, ул. Профсоюзная, 84/32 E-mail: ovsinfo@gmail.com

Abstract. Background. One of the pressing aims of today's natural resource management is its re-orientation to preserving and restoring ecological functions of ecosystems, among which the function of biodiversity maintenance plays an indicator role. The majority of today's forests have not retained their natural appearance as the result of long-standing human impact. In this connection, refugia studies are becoming particularly interesting, as they give us an insight into the natural appearance of forests. Materials and methods. Studies were performed in dark conifer forests of the Pechora-llych reserve, in the lower reaches of the Bol'shaya Porozhnyaya River in 2013 yr. Vegetation data sampling was done at 50 temporary square plots of a fixed size (100 $\mathrm{mz})$ randomly placed within a forest type. A list of plant species with species abundance was made for each forest layer. The overstorey (or tree canopy layer) was denoted by the Latin letter A. The understorey layer (indicated by the letter B) included tree undergrowth and tall shrubs. Ground vegetation was subdivided into the layers $C$ and D. Layer $C$ (field layer) comprised the herbaceous species (herbs, grasses, sedges) and dwarf shrubs together with low shrubs, tree and shrub seedlings. The height of the field layer was defined by the maximal height of the herbaceous species, ferns, and dwarf shrubs; the height varied from several cm to more than $200 \mathrm{~cm}$ in the 'tall-herb' forest types. Layer $D$ (bottom layer) included cryptogamic species (bryophytes and lichens). Species abundance in the each layer was usually assessed using the Braun-Blanquet cover scale (Braun-Blanquet 1928). The nomenclature used follows Cherepanov's (1995) for vascular plants, and Ignatov \& Afonina's (1992). Results. The present article contains descriptions of unique tall-herb boreal forests of European Russia preserved in certain refugia which did not experience prolonged anthropogenic impact or any other catastrophes. Comparative research into species and ecological diversity of typical (anthropogenically transformed) and unique (tall-herb) boreal forests has been conducted. On the basis of the collected field data, a map of the diffuse area for tall-herb boreal forests has been compiled and a set of species characteristic for these forests has been determined. The obtained data fundamentally change our notions of potential vegetation in boreal forests. Conclusions. Considerable species- and ecological diversity of tall-herb forest flora fundamentally changes our notion of the appearance of European boreal forests and determines their unique role in maintaining the highest possible level of biodiversity. The presence of 
tall-herb forests in various parts of eastern European taiga together with Eurasian habitats of most tall-herb species lead us to a suggestion that it is exactly this type of forests that represented the prehistoric boreal forests. In this connection, further research into still preserved fragments of tall-herb forests within the boundaries of northern Eurasia acquires huge significance. This research will help put forward systems of forest management aimed at restoring potential biodiversity of boreal forests in general.

Key words: taiga (boreal forests), human impact, biodiversity, green moss spruce-fir forests, tall herb spruce (-fir) forests, refugia of prehistoric boreal forest, signs of undisturbed boreal forest.

For citation: Aleinikov A.A., Smirnov N.S., Smirnova O.V. Tall-Herb Boreal Forests on North Ural. Russian Journal of Ecosystem Ecology. 2016;1(3). Available from: https://doi.org/10.21685/2500-0578-2016-3-3

Аннотация. Актуальность и цели. Актуальные задачи современного природопользования - его переориентация на сохранение и восстановление экологических функций экосистем, среди которых индикаторную роль играет функция поддержания биоразнообразия. Большая часть современных лесов утратила природный облик вследствие длительного антропогенного воздействия. В связи с этим особый интерес приобретают исследования лесов в рефугиумах, существующих многие сотни лет без антропогенных воздействий. Цель исследований выявить и охарактеризовать состав и структуру уникальных высокотравных лесов Северного Урала и на этой основе составить перечень признаков, характеризующих природные таежные леса Европейской России. Материалы и методы. Для достижения поставленной цели проведены геоботанические и почвенные исследования в двух контрастных типах бореальных лесов: наиболее широко распространенном типе пихто-ельнике зеленомошном и в уникальном типе пихто-ельнике с кедром высокотравным. Геоботанические, почвенные и популяционно-онтогенетические исследования проведены по общепринятым методикам; типы сообществ охарактеризованы в соответствии с разработанной ранее эколого-ценотической классификацией лесов Европейской России (http://mfd.cepl.rssi.ru/forest). По натурным данным составлена карта точечного ареала высокотравных таежных лесов и определен комплекс видов, маркирующих эти леса. Результаты. Сопоставление двух исследованных типов бореальных лесов показало, что высокотравные леса обладают полным набором признаков, характеризующих длительно существующие в спонтанном режиме природные леса: полночленные онтогенетические спектры ели и пихты, полностью сформированный микрорельеф, значительное видовое богатство и видовая насыщенность, огромное эколого-ценотическое и экологическое разнообразие флоры сосудистых растений. Полученные результаты дали возможность реконструировать природный облик таежных лесов анализируемой территории. Анализ ареала высокотравных бореальных лесов позволил заключить, что именно такие леса были распространены на большей части территории Европейской России и Западной Сибири в доисторические времена. Выводы. Полученные данные существенным образом меняют представление об облике европейской тайги. Находки высокотравных лесов в различных частях восточноевропейской тайги, а также евразийские ареалы большей части высокотравных видов позволяют предположить, что именно такие леса представляли доисторический облик тайги. В связи с этим огромное значение приобретают углубленные исследования еще сохранившихся в пределах Северной Евразии фрагментов высокотравных лесов. Такие исследования позволят предложить системы лесопользования, направленные на восстановление потенциального биологического разнообразия таежных лесов в целом.

Ключевые слова: тайга (бореальные леса), антропогенные воздействия, рефугиумы биоразнообразия, зеленомошные пихто-ельники, высокотравные пихто-ельники, признаки доисторических бореальных лесов.

\section{Introduction}

At present, boreal forests of the Northern Hemisphere are attracting close attention of various experts. On the one hand, these forests are a valuable commodity still preserved in vast little accessible areas, especially across our country. On the other hand, with tropical and subtropical forests being destroyed at an increasingly fast rate, boreal forests are beginning to play an ever-increasing role in fulfilling ecosystem functions of forests in general. These functions include biotic optimization of the climate and hydrological regime, biogeochemical cycle regulation, biodiversity maintenance and others [1-3]. For this reason, evaluation of boreal forest ecosystem functions (first and foremost, evaluation of the highest possible level of biodiversity) is gaining particular significance.

\section{Materials and methods}

Studies were performed in dark conifer forests of the Pechora-Ilych reserve, in the lower reaches of the Bolshaya Porozhnyaya River in 2013. Vegetation data sampling was done at 50 temporary square plots of a fixed size $\left(100 \mathrm{~m}^{2}\right)$ randomly placed within a forest type. A list of plant species with species abundance was made for each forest layer. The overstorey (or tree canopy layer) was denoted by the Latin letter A. The understorey layer (indicated by the letter B) included tree undergrowth and tall shrubs. Ground vegetation was 
subdivided into the layers C and D. Layer C (field layer) comprised the herbaceous species (herbs, grasses, sedges) and dwarf shrubs together with low shrubs, tree and shrub seedlings. The height of the field layer was defined by the maximal height of the herbaceous species, ferns, and dwarf shrubs; the height varied from several $\mathrm{cm}$ to more than $200 \mathrm{~cm}$ in the 'tall-herb' forest types. Layer D (bottom layer) included cryptogamic species (bryophytes and lichens). Species abundance in the each layer was usually assessed using the BraunBlanquet cover scale (Braun-Blanquet 1928). The nomenclature used follows Cherepanov's (1995) for vascular plants, Ignatov \& Afonina's (1992).

\section{Results}

In accordance with the dominant-ecocenotic classification by L. B. Zaugolnova (http://mfd.cepl.rssi.ru/ flora), the following forest types have been analyzed: (1) Piceeta (Abieta) fruticoso-hylocomiosa dwarf shrub - green moss spruce-fir forests; (2) Piceeta (Abieta) magnoherbosa - boreal tall herb spruce(-fir) forests. We estimated plant diversity (alpha diversity) for each forest type by calculating total species richness of each forest type and species richness per square unit, i.e. species density according to Hurlbert (1971). Species density was calculated as the average number of species per sample plot of fixed size within a forest type.

Piceeta (Abieta) fruticoso-hylocomiosa dwarf shrub - green moss spruce-fir forests (green-moss taiga).

Prolonged human impact on boreal forests (known in Russian research as northern and central taiga forests) such as clear cutting, grazing, forest litter removal, periodic man-caused forest fires, have led to formation of low productive plant communities with low biodiversity across vast territories. These are represented by green-moss spruce forests across most of the Russian Plain and silver fir and spruce forests in the east of it, as well as in the Urals and West Siberia. As of today, it is exactly this type of forests that is considered natural. The following statements, made by A. I. Tolmachev and cited across Russian research community, confirm the abovementioned, "The natural aspect of the taiga zone is obvious to each and every. The taiga is the most wide-spread type of vegetation outside the tropical latitudes of the Northern Hemisphere" [4, p. 8]. "A typical darkconiferous taiga is not only characterized by a limited set of dominant tree species, but also by the overall humble flora composition. Poor vegetation coverage is in harmony with the limited species composition; plants living beneath the canopy of the dark-coniferous forest form negligible biomass only..." [4, p. 11].

According to the literature data $[5,6]$, a typical dark-coniferous taiga is wide-spread across drained water-dividing areas of the Russian Plain, in the Urals and West Siberia. Such forests are represented by green-moss forests with dwarf shrubs and green-moss short grass forests dominated by spruce or spruce and fir with a fraction of the Siberian pine. The canopy of such forests is usually formed by same generation trees; the understorey is sparse and is represented by poorly developed species; species composition and ecologicalcoenotic diversity of herbs and small shrubs is minimal. The moss cover in such forests, on the contrary, is very well developed and is dominated by green boreal mosses (Fig. 1). The moss forms a prominent layer of slowly decomposing forest litter, poor in minerals and characterized by rapidly changing moistening cycles. This layer quickly gets wet and dries up just as quickly. Such a variable moistening cycle is unfavorable for advance growth as well as many small shrubs and herbs. Moreover, dry moss cover is in fact a combustible substance, which significantly contributes to the vast spread of forest fires.

As adult trees are small in size, their surface root system is poorly developed and most trees are contaminated by fungal pathogens, death of trees is not accompanied by pedoturbations: twisting of root systems together with earth clods and formation of mounds or pits. The trunk of an old tree usually breaks off at the base when the tree dies. Over time, tree trunks and crowns plunge into the moss cover, gradually getting covered with green mosses. The moss cover of fallen trees becomes populated by pinewood and boreal shrubs: lingonberry (Vaccinium vitis-idaea), blueberry (Vaccinium myrtillus L.) and small boreal herbaceous plants - wood sorrel (Oxalis acetosella), chickweed wintergreen (Trientalis europaea), and May lily (Maianthemum bifolium) [7, 8]. These plants obtain the necessary moisture from decomposing fallen trees, which unlike the moss cover preserve it for a long time.

The spruce is the only tree species that most often regenerates on decomposing moss-covered tree trunks (Fig. 2). Absolute dominance of this species does not only reduce the overall biological diversity due to ultimate homogeneity of tree synusia, but also enhances prevalence of fungal diseases among trees. Layering of the ground cover is almost unpronounced: green mosses and small herbaceous plants exist within one storey; assimilating shrub organs (young blueberry and lingonberry shoots) only slightly exceed the height of the moss cover. 


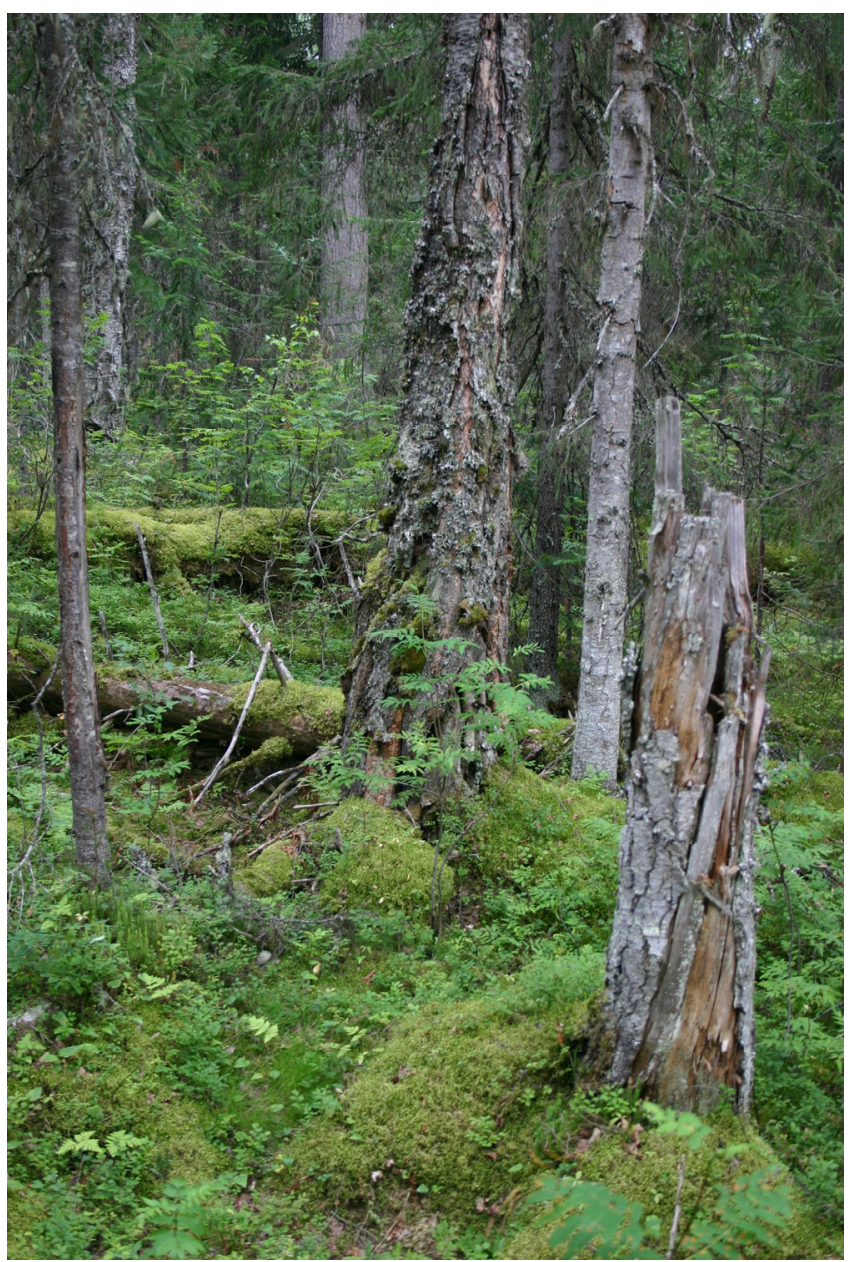

Fig. 1. Overall look of the green-moss spruce forest. National park "Paanaiarvi (North Karelia)". By M. V. Bobrovsky

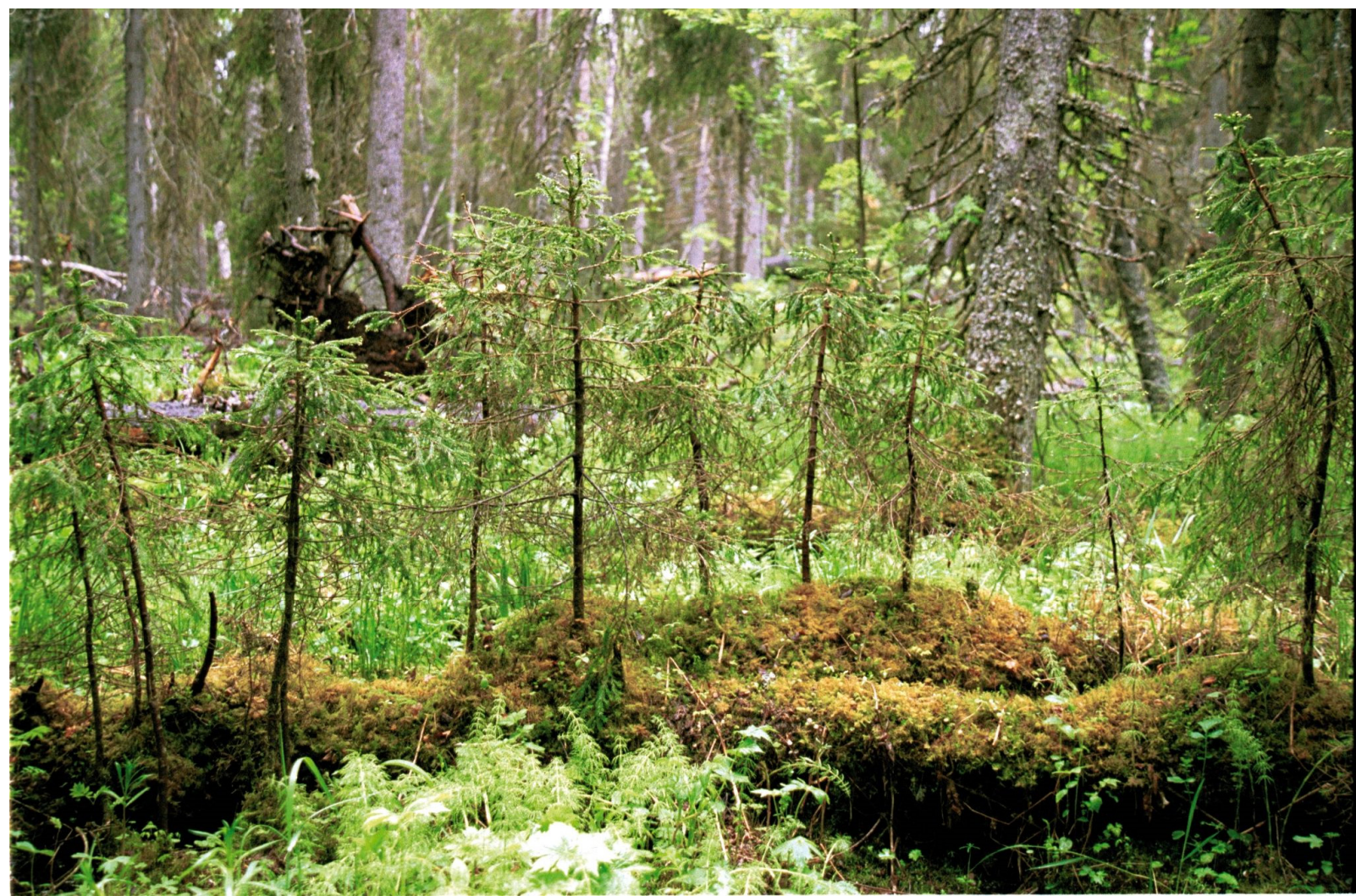

Fig. 2. Regeneration of the spruce on the fallen dead wood.

National park "Paanaiarvi (North Karelia)". By M. V. Bobrovsky 
Green moss forests have been formed under the influence of clear or selective cutting, as well as fires. Some traces of past fires may be detected in them in the form of scorch marks on old pines or cedars and soil composition. Soil types here are predominantly illuvial- ferric, illuvial-humus-ferric podzols and podzolic soils (Fig. 3). The humus thickness is very small or absent altogether. Continuous presence of coal is one of the characteristic features of the soil

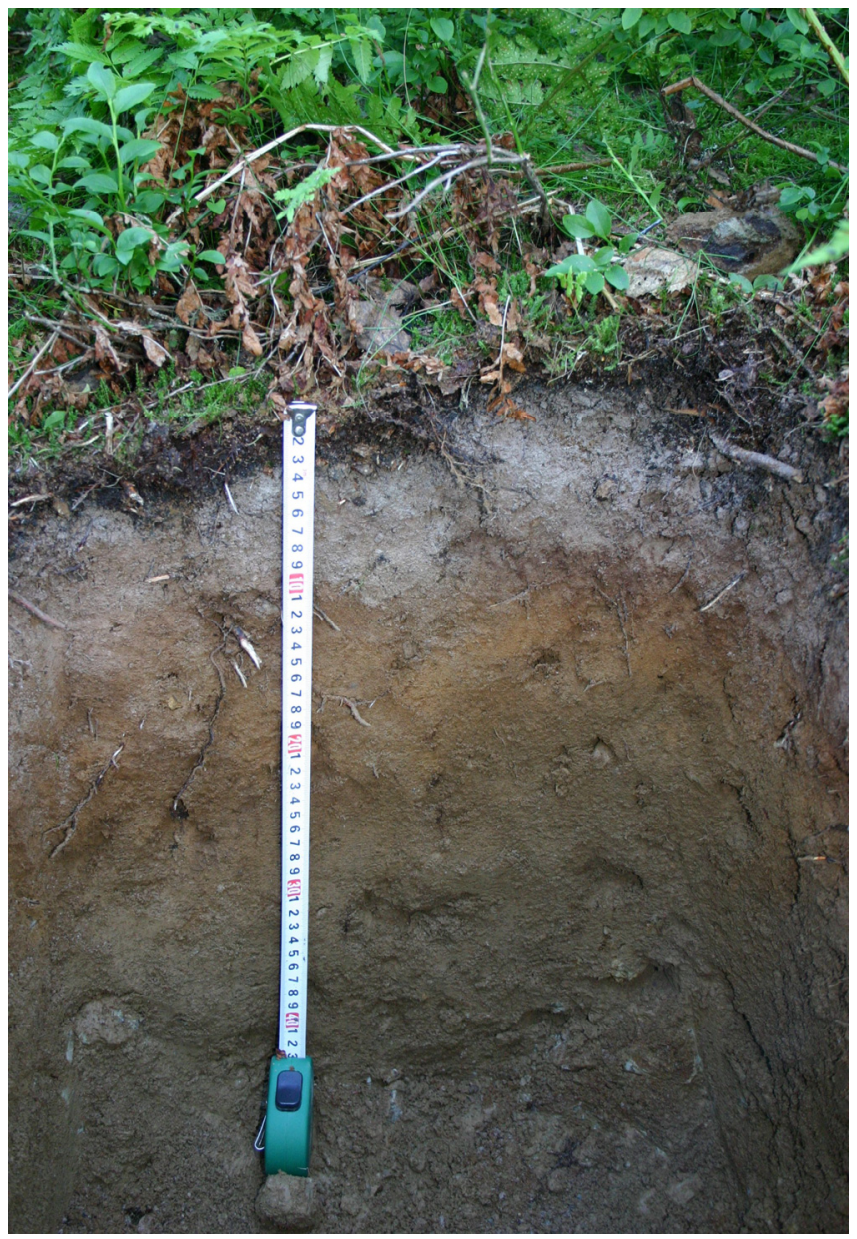

Fig. 3. Illuvial-ferric podzol in a blueberry green-moss forest. By A. D. Bovkunov

Piceeta (Abieta) magnoherbosa - boreal tall herb spruce(-fir) forests (peony taiga).

Despite being a wide-spread boreal forest type, dark-coniferous green-moss forests with low species diversity are far from being the only type of boreal forests. This has been backed by results of detailed research into dark-coniferous forests in nature reserves, as well as by research into the historical archives data and cartographic data covering the history of forest management [9-12]. Years of research have uncovered considerable diversity of dark-coniferous boreal forests [11]. A unique type of tall-herb boreal forests has been specifically marked out (research by Zaugolnikova, 2009) amongst the diversity of such forests and closely examined. In the west of the examined site (west and centre of the Russian Plain)
(Fig. 4). In most soils foliated coal was encountered in the form of a layer on the borderline between the forest floor and the mineral horizon. The coal layer thickness occasionally reaches several centimeters, which testifies to multiple crown and surface fires in the past [9]. The anthropogenic nature of most fires in boreal forests has been repeatedly confirmed by observations and recorded in materials produced by nature reserves $[3,10]$.

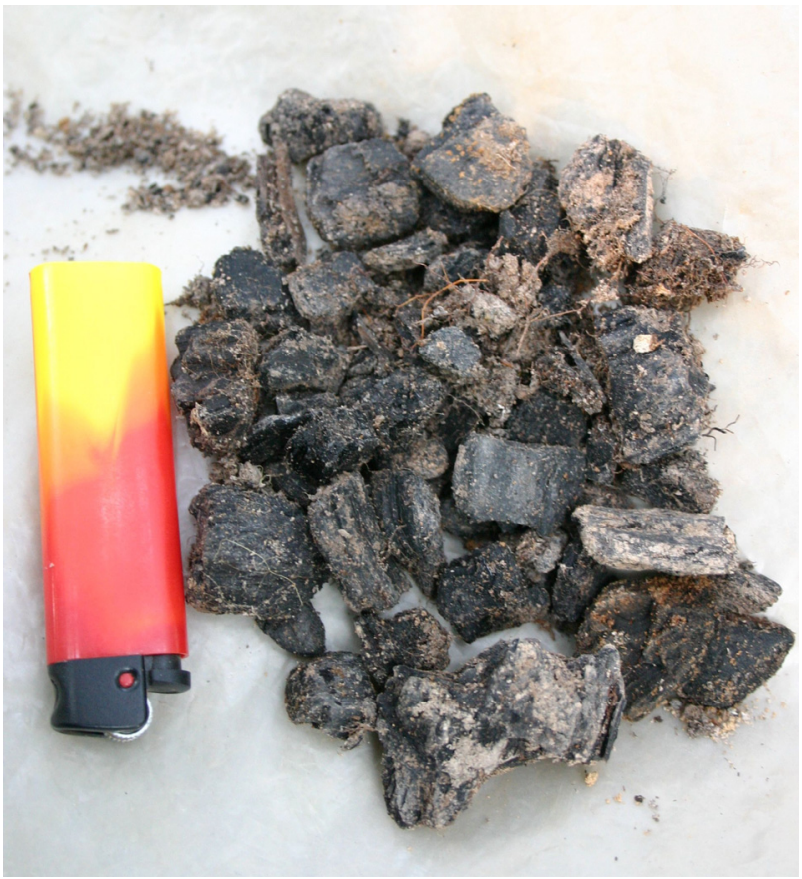

Fig. 4. Coals from soil cuts of spruce and fir green-moss forests. Pechora-llych Nature Reserve.

By M. V. Bobrovsky

these forests are represented by spruce tall-herb forests (Piceeta magnoherbosa), in the east (east of the Russian Plain, in the Urals and West Siberia) - by spruce and fir forests with tall-herb cedar (PiceetoAbieta magnoherbosa).

Although detailed research into tall-herb darkconiferous forests started some 15 years ago, at the present moment these forests have been described for European Russia, from Northern Karelia to the Urals and for certain parts of West Siberia - in a vast range of climate conditions: from northern to southern boreal forests. Moreover, a unique area of boreal tall-herb forests was described outside of the forest belt, in the shrub tundra of the GornoKhadatinsk state nature reserve in the YamalNenets Autonomous District (Fig. 5). 


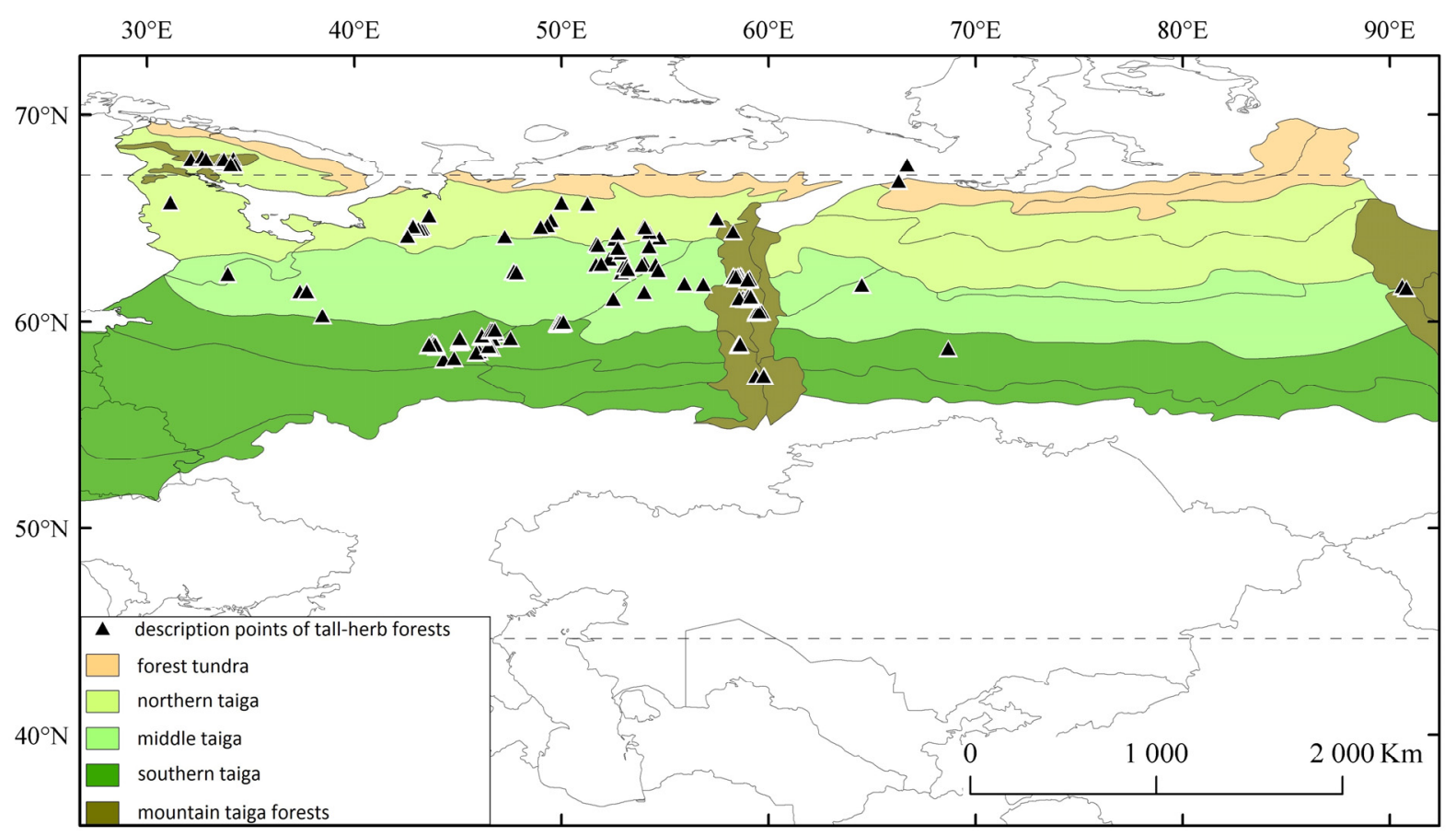

Fig. 5. Diffuse area of tall-herb dark-coniferous forests

Tall-herb forests can be found in areas with various relief features and substrate surfaces $[8,13]$. The majority of descriptions deal with forests located in the eastern part of the East European Plain and the Urals, probably because overall forests in those areas are better preserved.

In terms of their physiognomy, tall-herb forests are fundamentally different from green-moss boreal forests according to the following features. Their forest floor is dominated by tall-herb herbaceous flowering plants while the proportion of green mosses in the forest floor is minimal; green-mosses prevail in specific habitats, such as on fallen dead trees in the first stage of decomposition and overgrowth; accumulations of trees and large meadows are interspersed.

One of the most beautiful and wide-spread herbaceous plants of the boreal tall-herbs is Paeonia anomala, commonly known as the peony. This plant has been selected as a marker species for tall-herb forests (Fig. 6). The unusual appearance of peony-dominated tall-herb forest has given a name to the present article: peony taiga (Fig. 7).

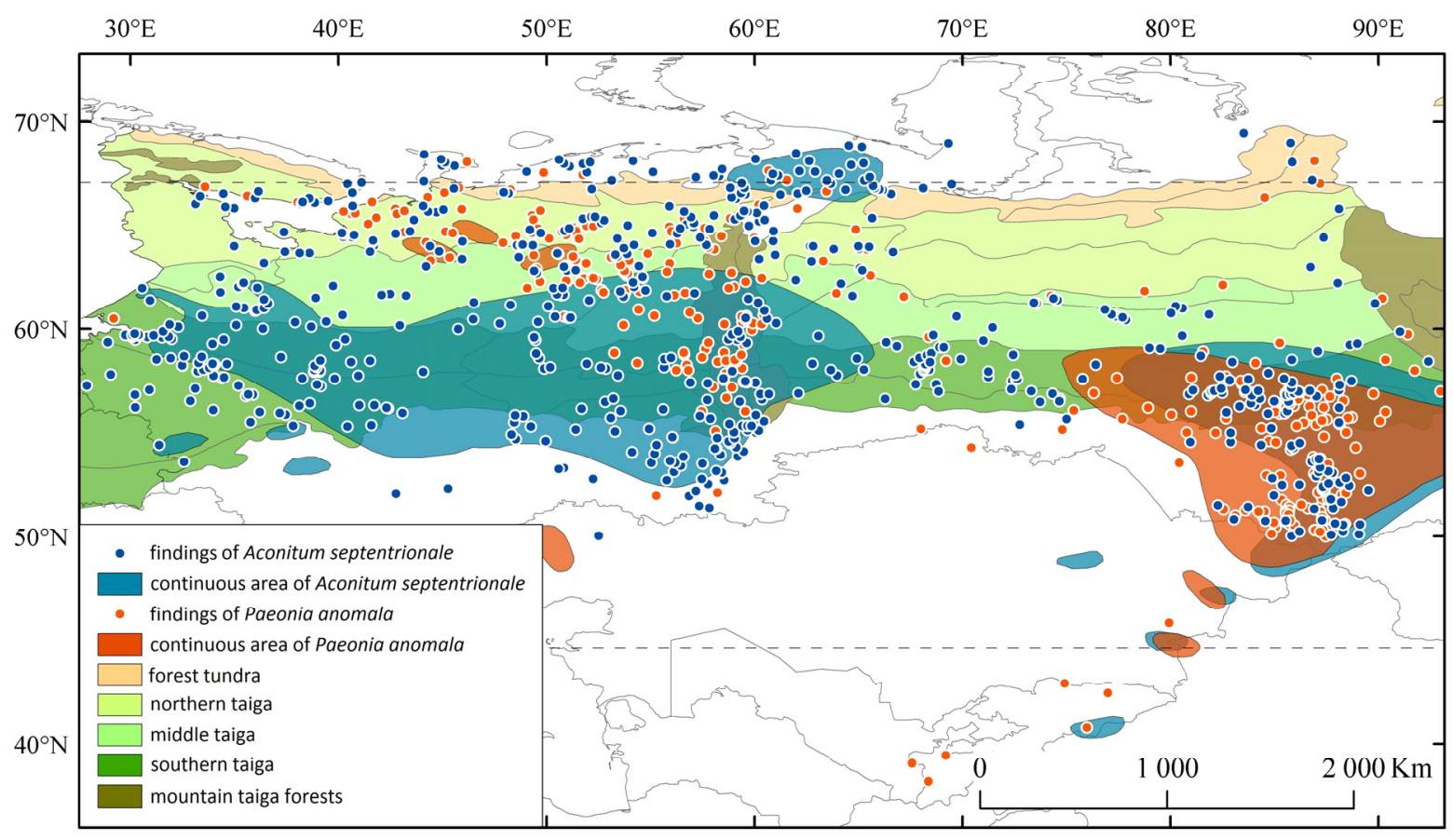

Fig. 6. Natural area of the peony and the aconite 


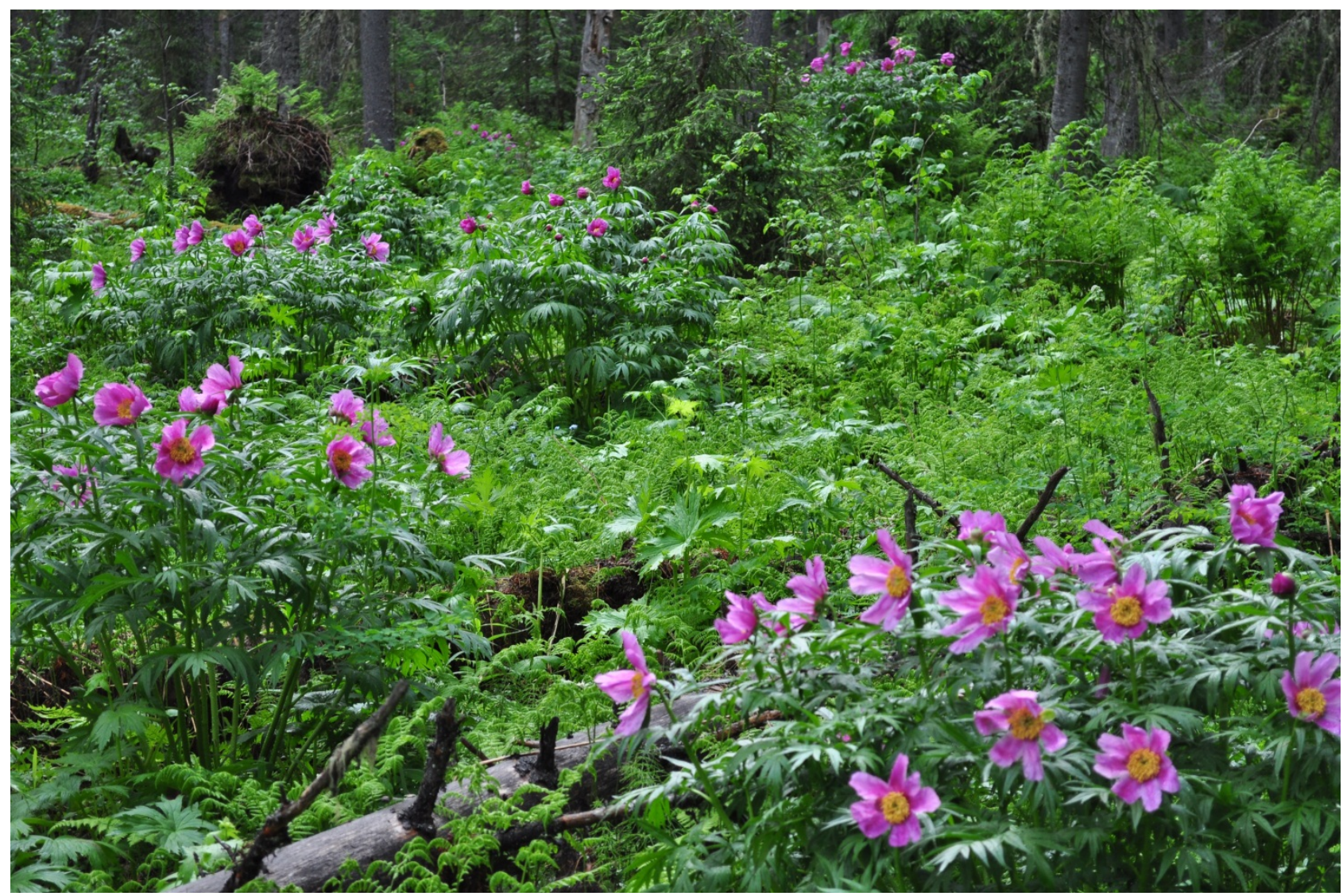

Fig. 7. Tall-herb dark-coniferous forest in the phase of peony flowering. Pechora-Ilych Nature Reserve. By A. A. Aleinikov

Dark-coniferous tall-herb forests differ drastically from green-moss forests according to the majority of features. Their stands of trees are uneven-aged and comprise uneven-aged groups of trees. The prevalent tree species are spruce or spruce and fir jointly; populations of these species are normal fullmember ones, which testifies to the stable flow of generations. Birch, poplar, and other deciduous trees as well as the Siberian pine grow in small numbers in the Cis-Ural region, the Urals and West Siberia. In these forests accumulations of trees of various size and age are interspersed with large glades, dominated by beautifully flowering tall herbs.

\section{The multiple layers of tall-herb taiga}

Tall-herb taiga has a multiple-layer polydominant ground vegetation cover. The first layer is dominated by boreal tall herbs species and has some large ferns. The plants can be up to 1-1.5 (2) $\mathrm{m}$ tall, with a total projective cover of 80-95\%. The most common of these are: Paeonia anomalia, northern wolfsbane (Aconitum septentrionale Koelle), larkspur (Delphinium elatum L.), bugbane (Actaea erythrocarpa, Fisch.), Cacalia hastata L., globeflower (Trollius europaeus L.), hawksbeard (Crepis sibirica L.), Thalictrum minus L., broad buckler fern (Dryopteris dilatata (Hoffm.)) and Diplazium sibiricum (Turcz. ex Kunze) Sa. Kurata).
According to 850 geobotanical descriptions currently collected, there are 45 species of tall herb forests: 41 species of flowering plants and 4 species of ferns (List of species). Comparative analysis of data on the habitat of these species using the "Areal" database (compiled by T. S. Prokazina from literature and herbarium materials) has demonstrated the following break-down: 2 species are Ural endemics, 2 species - Euro-Siberian, 4 - Holarctic, 6 - European, and 31 out of the species 45 analyzed are Eurasian.

The fact that tall herb forests are dominated by species with Eurasian habitats gives evidence of how wide-spread these forests were in the past. Comparative analysis of habitat maps for the most wide-spread tall-herb species is essential for a larger search for tall herb forests in Russia's eastern regions.

The second layer of ground vegetation in these forests is also quite peculiar. It is inhabited by nemoral grasses. The latter include both the early spring species or ephemeroids (Fig. 8) such as: $\mathrm{Co}$ rydalis bulbosa (L.) DC, yellow Star-of-Bethlehem (Gagea lutea L. Ker-Gawl.) and Anemone altaica Fisch. ex C.A; and the summer-vegetating species such as: spring vetchling (Lathyrus vernus (L.)), wood millet (Milium effusum L.), herb paris (Paris quadrifolia L.) and greater stitchwort (Stellaria holostea L.). Their total cover reaches 10-20\%. 


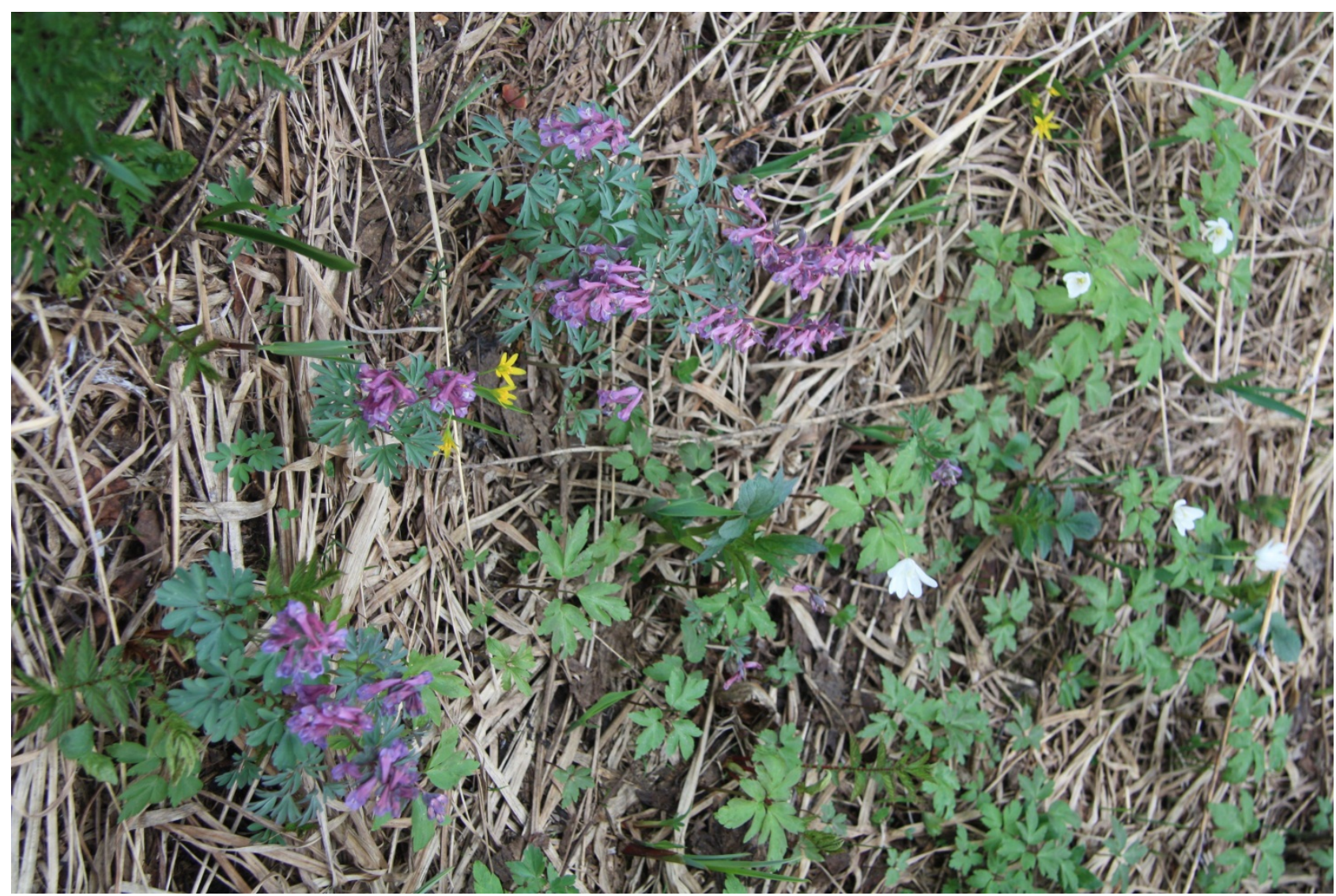

Fig. 8. Ephemeroids: Corydalis bulbosa (L.) DC, yellow Star-of-Bethlehem (Gagea lutea L. Ker-Gawl.) and Anemone altaica Fisch. ex C.A on a tall-herb forest glade in spring. Pechora-llych Nature Reserve. By A. S. Efimenko

Nemoral species, and especially ephemeroids, whose above-ground growth is before the canopy formation, are closely connected to broadleaves and aspen in terms of their habitat. Therefore, their presence in dark-coniferous boreal forests looks unexpected. However, the reconstruction of broadleaf trees' habitats in the late Holocene has demonstrated that they were spread much further to the north than at present [14]. Consequently, we may presume that their presence in dark-coniferous forests marks a wider spread of broadleaves to the north in the past. We have to note that ephemeroids have only been preserved in tall-herb forests which are characterized by rich soils with moistureholding capacity. They remain mostly on glades where coniferous trees are absent and where in spring and at the beginning of summer, when vegetation is just starting, there is quite enough light.

The third layer of ground vegetation cover is inhabited by small herbaceous plants: wood sorrel (Oxalis acetosella), chickweed wintergreen (Trientalis europaea), May lily (Maianthemum bifolium) and other species, continuously present in green moss forests. Their cover reaches 10 to $20 \%$.

The fourth layer is formed by surface-tending hemiboreal mosses of the genus Plagiomnium, joined by Barbilophozia lycopodioides, Brachythe- cium reflexum, Rhizomnium magnifolium, Rhodobryum roseum and others. Their cover reaches 5 to $10 \%$. Those species are rarely present in green moss forests. It should be emphasized that boreal green mosses, characteristic of green-moss dark-coniferous forests, such as Pleurozium schreberi (Brid.) Mitt and Hylocomium splendens (Hedw.) Schimp. in B.S.G., do not grow on soil in tall-herb forests. Trunks of large dead trees remain the sole habitat where those mosses are both present and dominant. Here in early stages of overgrowth these mosses form a complete cover (cover reaching 90-95\%), with humble presence of small boreal herbs and blueberry.

Another wonderful feature of tall-herb forests consists in the following fact: at the bases of large spruce and Siberian pines one can find lingonberry (Vaccinium vitis-idaéa L.) and lichens of genera Cladonia and Cladina - typical dwellers of lichen pine forests. This amazing variety of ecologicalcoenotical communities in the ground-vegetation cover of tall-herb forests is the result of a large diversity of plant microhabitats.

In addition to downed dead wood, pits and mounds are a common feature of tall-herb forests. Pits are formed when falling trees turn out clods of earth together with the root system. Mounds are 
formed from clods of overturned earth and skeleton roots of dead trees (Fig. 9). The pits are often inhabited by nitrophilic plants that frequently inhabit near-river alder forests such as alternateleaved golden saxifrage (Chrysosplenium alternifolium L.), wood stitchwort (Stellaria nemorum L.), and mead wort (Filipendula ulmaria (L.). Mounds are inhabited by meadow species such as Bush vetch (Vicia sepium L., Poa pratensis L.), mead- ow-grass (Poa pratensis) and others. As fallen dead wood is decomposing, pits and mounds overgrow, the more narrowly specialized species of these microhabitats are replaced with generalist species: the nemoral ones come first, followed by tall-herb ones. As downed dead wood, mounds and pits are being constantly formed, there is always a vast diversity of ecologically distinct vascular plants and mosses in tall-herb forests [15].

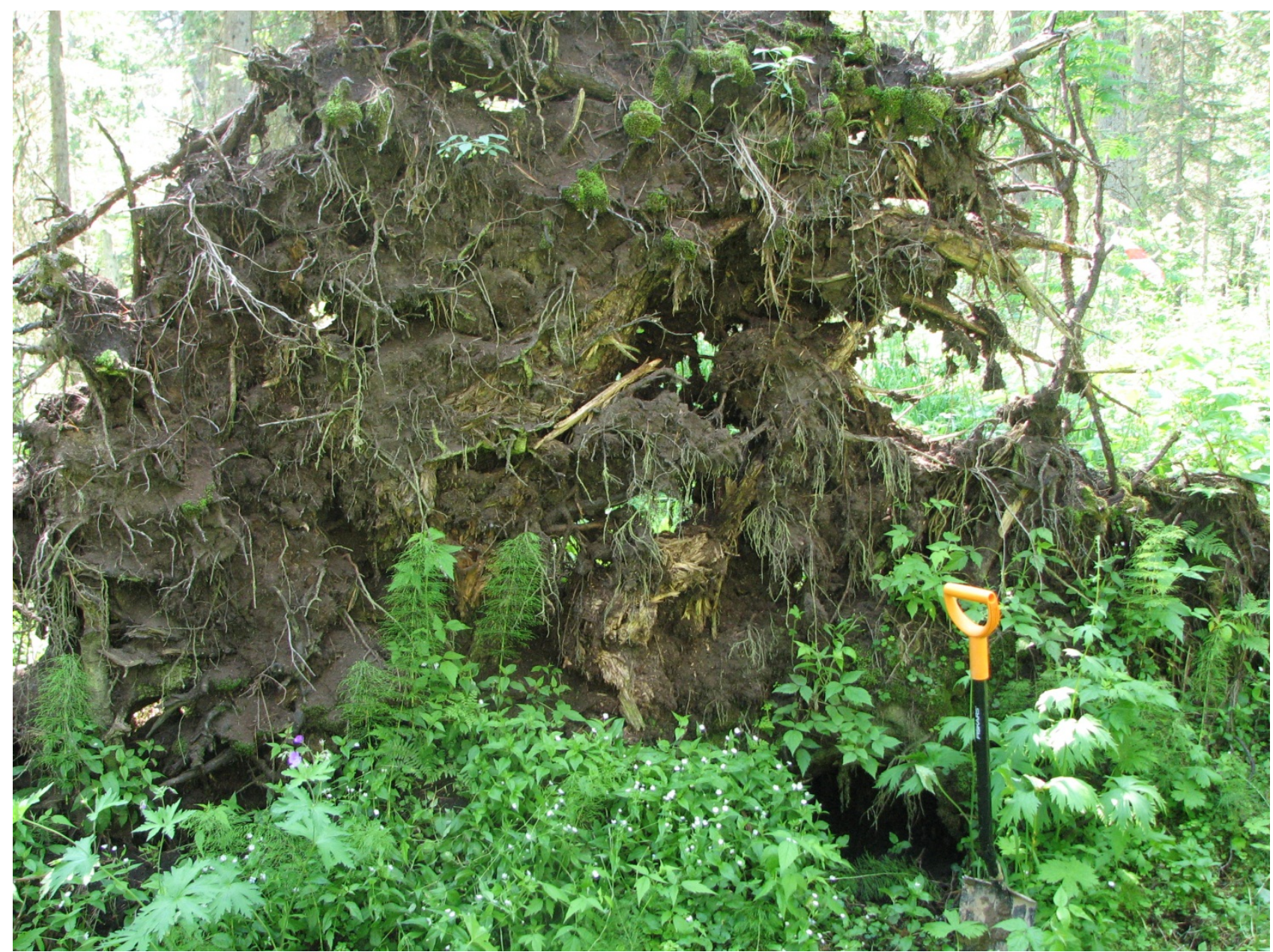

Fig. 9. Elements of the soil complex attributable to windthrow: a mound and a pit in a tall-herb forest. Pechora-llych Nature Reserve. By A. A. Aleinikov

The most common types of soils for tall-herb forests are brown soils (either common or coarse-humus types) (Fig. 10). Their distinctive features are: a well-structured humus horizon, up to $30-60 \mathrm{~cm}$ thick (and above), relatively high organic matter content $(3,5-5,5 \%)$, neutral to mildly-acidic $\mathrm{pH}(5,0-6,2)$, ample supply of calcium, potassium and phosphorus compared to other boreal forest soils. In contrast to green moss forests, tall-herb forest soils have high moisture-retention capacity, which significantly reduces likelihood of fires. No signs of previous fires were detected in soil profiles, in the majority of tall-herb watershed forests examined [15].
Comparative studies of vegetation and soil specificities in dark-coniferous tall-herb forests and green-moss forests have fundamentally altered our notions of the natural look of the least perturbed natural boreal forests.

\section{Signs of undisturbed boreal forest}

To date large amounts of information about forest dynamics have been collected in eastern European nature reserves. Plant communities which live in similar ectopic (external) habitat conditions, but with different lifespans and types of anthropogenic adverse effects, have been identified. These find- 
ings allowed identifying a set of indicator features to determine the successional state of forest communities:

- percentage ratio of total basal areas in early successional (pioneer) to late successional (climax) species in tree synusia;

- types of ontogenetic spectra of late successional tree species;
- presence of soil complexes attributable to windthrow (mounds, pits and felled wood);

- diversity of the ecological-coenotical structure of the forest floor;

- species richness (number of species characteristic of the community) and species saturation (number of species per unit of surface) of vascular plants and mosses in the forest floor.

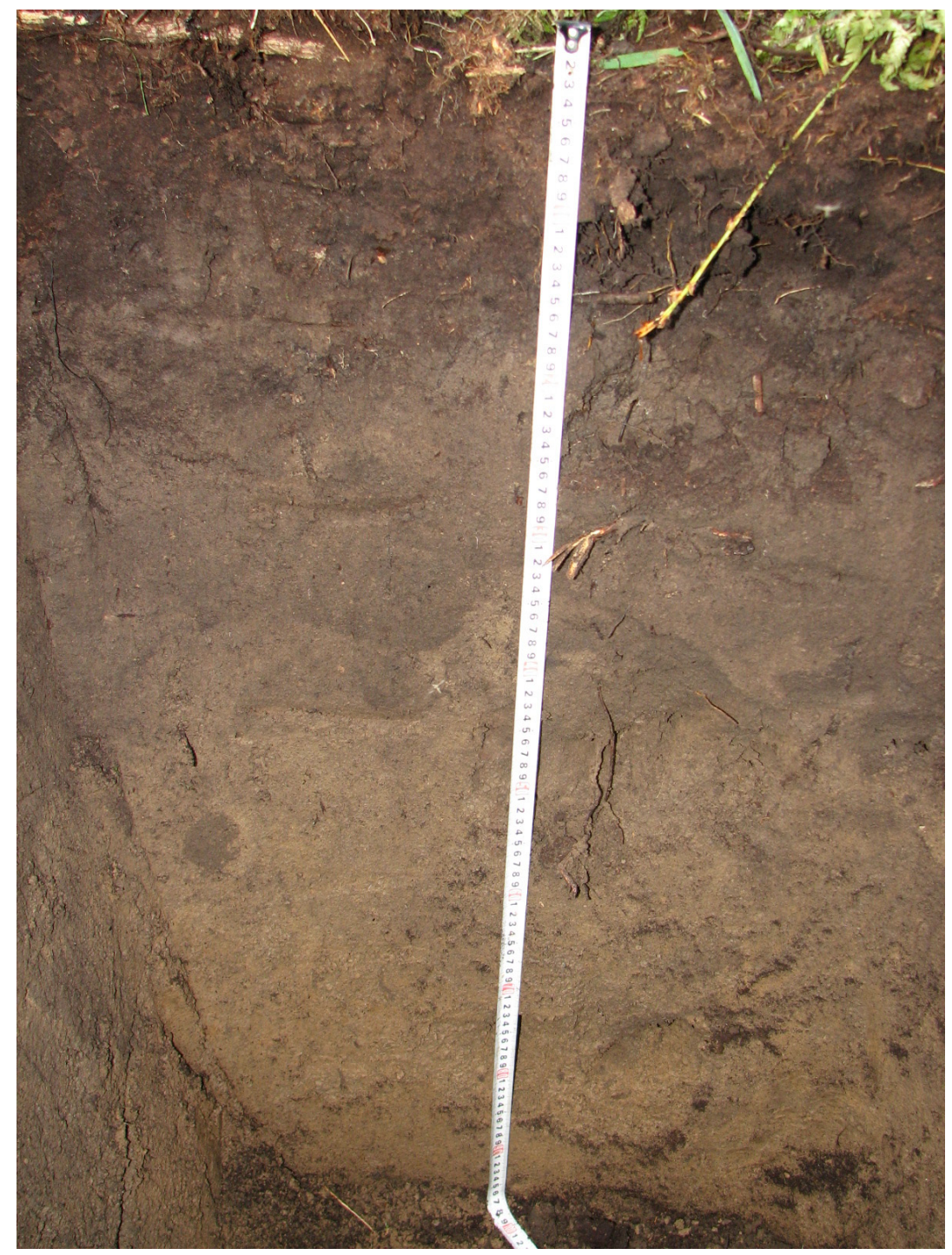

Fig. 10. Coarse-humus brown soil in a tall-herb forest. Pechora-Ilych Nature Reserve. By A. D. Bovkunov

Analyzing changes of these indicators obtained by studying forest communities with similar substrates (by age of anthropogenic disturbances), we have detected the following patterns in the changes of indicator features during the regeneration processes of natural forest's appearance (autogenic successions):

1. Total basal area of pioneer species in the early stages of natural succession is nearing $100 \%$. In the final stages, with the basal area of climax species does not exceed 5-15\%.

2 . In the middle stages of succession, populations of climax tree species are invasive; in the fi- nal stage these are normal saturated ones which attests to the sustainable generation flow.

3 . In the middle stages of succession, systems of first-stage microhabitats (mounds, holes and felled trees) are formed in the community, while in the end stages microhabitat elements of all transformation stages have been formed in approximately equal proportions.

4. In the early stages of community development, after the canopy of the coniferous species has closed, the ground vegetation is represented by species of one or two ecological-coenotical groups, which attests to the fact that systems of microhabi- 
tats are immature. In the end stages there are species from all, or the majority of ecologicalcoenotical groups. The latter fact reflects the greatest possible diversity of microhabitats.

5. In the early stages of community development, after the canopy of the coniferous species has closed, species richness (number of species characteristic of the community) and species saturation (number of species per unit of surface) are minimal. In the late stages, both reach their maximum for the given area. Thus, there is a favorable combination of the following features: microhabitat diversity, and the presence of the primordium (seeds and spores) within the spread boundaries, capable of colonizing these or those microhabitats.

A comparative study of green-moss and tall-herb dark-coniferous forests (http://mfd.cepl.rssi.ru/ forest) against the listed features demonstrated that it is exactly tall-herb forests that are characterized by the highest prominence of the above- mentioned features.

The ontogenetic spectra of spruce and fir are normal, saturated in those communities, which attests to the sustainable generation flow. There is a full range of soil complexes attributable to windfall, which ensures continuous maintenance of internal heterogeneity of tall-herb forests $[16,17]$. Species richness of vascular plants in different parts of the studied area reaches 150-200 species, with local species saturation of 40-60 species per $100 \mathrm{~m}^{2}$. Tall herbs dominate the ground vegetation layer; according to total coverage and biomass, tall herbs dominate the ground vegetation layer; the proportion of mosses is minimal. In green-moss forests all these indicators are substantially lower.

For the sake of comparison, we would like to provide some results obtained in the same areas and similar relief positions in green-moss spruce forests and spruce and fir forests. Species richness of vascular plants is $30-50$ species, species saturation amounts to $5-10$ species per $100 \mathrm{~m}^{2}$. The ground vegetation layer is dominated by green mosses according to such parameters as total cover and biomass $[8,15]$.

Evaluation of the current state of tall-herb coniferous forests against the indicator features has resulted in the following conclusion: these forests are in their final stage of regeneration after disturbances, while green moss forests are in the middle stage of regeneration. Judging by the presence of coal in soils of most boreal forests, intense crown fires are the most likely cause of disturbances.

According to preliminary radiocarbon dating in tall-herb forests of the Pechora-Ilych nature reserve, the latest fires date back to $600-1000$ and more, whereas in green moss forests fires date back to no more than 200-250 years.

It is quite likely that part of the examined tallherb forests have not experienced serious anthropogenic impact and represent refugia of genuinely natural boreal forests. However, at present it is impossible to clearly distinguish between these two types of tall-herb forests as their biodiversity has not been examined in full, and only the first data covering specificities of their structural and functional organization have been collected.

\section{Discussion The prehistoric face of taiga}

The results obtained allow reconstructing the natural look of boreal forests in the examined area. It may be suggested that it is exactly tall-herb forests that largely determined the pre-historic appearance of taiga in the examined area. This is evidenced by their spread from the northern boundaries of the forest belt to the southern taiga, their significant ecotopic diversity and their ability to survive in harsh climates, while preserving nemoral-boreal composition of flora.

This assumption largely echoes the theory on the origin of today's taiga zone which states that the former emerged from arctic forests of the tertiary period (i.e. forest widely spread in the polar region in Miocene) as a result of gradual climate change from the end of the Pleiocene Period until the end of the Pleistocene Period. This theory was independently formulated by A. I. Leskov [18] and V. B. Sochava [19], on the basis of biogeographical research, and by V. P. Grichuk [20] and P. I. Dorofeev [21], on the basis of paleobotanical research.

Accumulated data on the mixed nemoral-boreal composition of the herb and shrub storey of the tallherb coniferous forests can also be considered as an argument in favor of the above-mentioned theory $[13,22]$. This forest storey is characterized by cohabitation of diverse boreal species (from shrubs such as blueberries to tall herbs such as peony, aconites and delphiniums) and nemoral species (such as ephemeroids and summer vegetating ones).

To form the numeral-boreal herb-shrub storey, the following conditions are necessary: presence of deciduous tree litter (as nemoral species are more frequently seen under deciduous tree cover), holes and pits (commonly inhabited by nitrophilic plants and hemiboreal mosses), felled trees of 2-3 overgrowth stages (covered by small boreal herbs, small shrubs and boreal green mosses), crown gaps with dominating tall herbs and other features. It should be noted that presence of nemoral plants in 
the northern and middle taiga, which only has small-leaved trees, can indirectly indicate past presence of broadleaves there.

On the other hand, data collected on the highest level of biodiversity in tall-herb forests in contrast to all coniferous boreal forests of the analyzed territory examined up to the present moment allow us to regard these forests as the most significant objects for evaluating possibilities of fulfilling the function of biodiversity by the taiga forest cover. Tall-herb forests clearly stand out among all northern taiga forests with their species diversity, their ecosystem functions performance.

The research was conducted with the financial support of the Russian Foundation of Basic Research (RFFI), project number 13-04-01491a, Russian Academy of Sciences Presidium 'Living systems', and Russian Federation Presidential grant (MK-2102.2012.4).

\section{Conclusion}

Considerable species and ecological diversity of tall-herb forest flora fundamentally changes our notion of the appearance of European boreal forests and determines their unique role in maintaining the highest possible level of biodiversity. The presence of tall-herb forests in various parts of eastern European taiga together with Eurasian habitats of most tall-herb species lead us to a suggestion that it is exactly this type of forests that represented the prehistoric boreal forests. In this connection, further research into still preserved fragments of tall-herb forests within the boundaries of northern Eurasia acquires huge significance. This research will help put forward systems of forest management aimed at restoring potential biodiversity of boreal forests in general.

\section{References}

1. Curtis, I. A. Valuing ecosystem goods and services: a new approach using a surrogate market and the combination of a multiple criteria analysis and a Delphi panel to assign weights to the attributes / I. A. Curtis // Ecologic. Economics. - 2004. -Vol. 50, iss. 3-4. - P. 163-194.

2. Горшков, В. Г. Планетарный парниковый эффект и биотическая устойчивость климата Земли / В. Г. Горшков, А. М. Макарьева, К. С. Лосев // Известия РАЕН. Секция наук о Земле. - 2001. - Вып. 7. - С. 62-68.

3. Мониторинг биологического разнообразия лесов России: методология и методы / под ред. А. С. Исаева. М. : Наука, 2008. -453 с.

4. Толмачев, А. И. К истории возникновения и развития темнохвойной тайги / А. И. Толмачев. - М. ; Л. : Изд-во АН СССР, 1954. - 155 с.

5. Смирнова, О. В. Старовозрастные леса Пяозерского лесхоза северо-западной Карелии / О. В. Смирнова, В. Н. Коротков // Ботанический журнал. - 2001. - Т. 86, № 1. - С. 98-109.

6. Смирнова, О. В. Сукцессионный статус старовозрастных темнохвойных лесов Европейской России / О. В. Смирнова, М. В. Бобровский, Л. Г. Ханина, В. Э. Смирнов // Успехи современной биологии. - 2006. № 1. - C. 26-48.

7. Бобровский, М. В. Лесные почвы европейской России: биотические и антропогенные факторы формирования / М. В. Бобровский. - М. : Товарищество научных изданий КМК, 2010. - 359 с.

8. Восточноевропейские леса: история в голоцене и современность / ред. О. В. Смирнова. - М., 2004. Кн. $1,2 .-575$ c.

9. Сукцессионные процессы в заповедниках России и проблемы сохранения биологического разнообразия / под ред. О. В. Смирновой, Е. С. Шапошникова. - СПб., 1999. - 549 с.

10. Оценка и сохранение биоразнообразия лесного покрова в заповедниках Европейской России / под ред. Л. Б. Заугольновой. - М. : Научный мир, 2000. - 196 с.

11. Луговая, Д. Л. Микромозаичная организация и фитомасса напочвенного покрова в основных типах темнохвойных лесов Печоро-Илычского заповедника / Д. Л. Луговая, О. В. Смирнова, М. В. Запрудина, А. А. Алейников, В. Э. Смирнов // Экология. - 2013. - № 1. - С. 3-10.

12. Atlas of North European Vascular Plants, North of the Tropic of cancer : in 3 vol. / E. Hulten, M. Fries. Konigstein,1986. - Vol. 1-3. - $1172 \mathrm{p}$.

13. Lippmaa, T. Areal und Alterbestimmung einer Union (Galeobdolon - Asarum - Asperula Union) sowie das Problem der Charakterarten und Konstanten / T. Lippmaa // Acta Inst. Hort. Bot. Univ. Tartuensis. - 1938. Vol. $6(2-3)$. - P. 1-152.

14. Martin, P. S. Prehistoric Overkill The Global Model. Quaternary Extinction / P. S Martin. - Tucson, 1984. P. 1-198.

15. Meusel, H. Chorologie der zentraleuropaischen Flora / H. Meusel, E. Jager, E. Weinert. - Jena, 1965. - Bd. 1. - 258 s. ; Jena, 1978. - Bd. 2. $-259 \mathrm{~s}$.

16. Флора СССР. - 1937. - Т. 7. - 792 с.

17. Заугольнова, Л. Б. Высокотравные таежные леса восточной части Европейской России / Л. Б. Заугольнова, О. В. Смирнова, Т. Ю. Браславская, Д. Л. Луговая, Т. С. Проказина // Растительность России. - 2009. № 15 . - C. 3-26. 
18. Смирнова, О. В. Представление о потенциальном и восстановленном растительном покрове лесного пояса Восточной Европы / О. В. Смирнова, Е. Ю. Бакун, С. А. Турубанова // Лесоведение. - 2006. - № 1. C. 22-33.

19. Пространственная неоднородность почвенно-растительного покрова темнохвойных лесов в ПечороИлычском заповеднике / О. В. Смирнова, А. А. Алейников, А. А. Семиколенных, А. Д. Бовкунов, М. В. Запрудина, Н. С. Смирнов // Лесоведение. - 2011. - № 6. - С. 67-78.

20. Баранов, В. И. Этапы развития флоры и растительности СССР в третичном периоде / В. И. Баранов. - Казань : КГУ, 1954. - 362 с.

21. Лесков, А. И. Принципы естественной системы растительных ассоциаций / А. И. Лесков // Ботанический журнал. - 1943. - Т. 28, № 2. - С. 37-52.

22. Сочава, В. Б. Вопросы флорогенеза и филоценогенеза маньчжурского смешанного леса / В. Б. Сочава // Материалы по истории флоры и растительности СССР. - М. ; Л., 1946. - Вып. 1. - С. 283.

\section{References}

1. Curtis I. A. Ecologic. Economics. 2004, vol. 50, iss. 3-4, pp. 163-194.

2. Gorshkov V. G., Makar'eva A. M., Losev K. S. Izvestiya RAEN. Sektsiya nauk o Zemle [Proceedings of the Russian Academy of Natural Sciences. Series Earth Sciences]. 2001, iss. 7, pp. 62-68.

3. Monitoring biologicheskogo raznoobraziya lesov Rossii: metodologiya i metody [Monitoring Biological Diversity of Forests in Russia: Methodology and Methods]. Ed. by A. S. Isaev. Moscow: Nauka, 2008, 453 p.

4. Tolmachev A. I. K istorii vozniknoveniya i razvitiya temnokhvoynoy taygi [To the History of Origin and Development of Dark CONIFEROUS taiga]. Moscow; Leningrad: Izd-vo AN SSSR, 1954, 155 p.

5. Smirnova O. V., Korotkov V. N. Botanicheskiy zhurnal [Botany Journal]. 2001, vol. 86, no. 1, pp. 98-109.

6. Smirnova O. V., Bobrovskiy M. V., Khanina L. G., Smirnov V. E. Uspekhi sovremennoy biologii [Current Advances of Biology]. 2006, no. 1, pp. 26-48.

7. Bobrovskiy M. V. Lesnye pochvy evropeyskoy Rossii: bioticheskie i antropogennye faktory formirovaniya [Forest Soils of European Russia: Biotic and Anthropogenic Factors of Development]. Moscow: Tovarishchestvo nauchnykh izdaniy KMK, 2010, 359 p.

8. Vostochnoevropeyskie lesa: istoriya v golotsene i sovremennost' [East European Forests: History in the Holocene and the Present]. Ed. O. V. Smirnova. Moscow, 2004, bk. 1, 2, 575 p.

9. Suktsessionnye protsessy $v$ zapovednikakh Rossii i problemy sokhraneniya biologicheskogo raznoobraziya [Succession Processes in Russian Natural Reserves and the Problem of Preserving the Biodiversity]. Eds. O. V. Smirnova, E. S. Shaposhnikov. Saint-Petersburg, 1999, 549 p.

10. Otsenka i sokhranenie bioraznoobraziya lesnogo pokrova v zapovednikakh Evropeyskoy Rossii [Assessment and Preservation of Biodiversity of Forest Cover in Natural Reserves of European Russia]. Ed. by L. B. Zaugol'nova. Moscow: Nauchnyy mir, 2000, 196 p.

11. Lugovaya D. L., Smirnova O. V., Zaprudina M. V., Aleynikov A. A., Smirnov V. E. Ekologiya [Ecology]. 2013, no. 1 , pp. 3-10.

12. Hulten E., Fries M. Atlas of North European Vascular Plants, North of the Tropic of cancer: in 3 vol. Konigstein, 1986, vol. 1-3, 1172 p.

13. Lippmaa T. Acta Inst. Hort. Bot. Univ. Tartuensis. 1938, vol. 6 (2-3), pp. 1-152.

14. Martin P. S. Prehistoric Overkill The Global Model. Quaternary Extinction. Tucson, 1984, pp. 1-198.

15. Meusel H., Jager E., Weinert E. Chorologie der zentraleuropaischen Flora [ ]. Jena, 1965, vol. 1, 258 p.; Jena, 1978, vol. 2, 259 p.

16. Flora SSSR [Flora of the USSR]. 1937, vol. 7, 792 p.

17. Zaugol'nova L. B., Smirnova O. V., Braslavskaya T. Yu., Lugovaya D. L., Prokazina T. S. Rastitel'nost' Rossii [Plants in Russia]. 2009, no. 15, pp. 3-26.

18. Smirnova O. V., Bakun E. Yu., Turubanova S. A. Lesovedenie [Forest Studies]. 2006, no. 1, pp. $22-33$.

19. Smirnova O. V., Aleynikov A. A., Semikolennykh A. A., Bovkunov A. D., Zaprudina M. V., Smirnov N. S. Lesovedenie [Forest Studies]. 2011, no. 6, pp. 67-78.

20. Baranov V. I. Etapy razvitiya flory $i$ rastitel'nosti SSSR v tretichnom periode [Stages of Plant Development in the USSR in Tertiary Period]. Kazan: KGU, 1954, 362 p.

21. Leskov A. I. Botanicheskiy zhurnal [Botany Journal]. 1943, vol. 28, no. 2, pp. 37-52.

22. Sochava V. B. Materialy po istorii flory $i$ rastitel'nosti SSSR [Data on the History of Flora and Plants of the USSR]. Moscow; Leningrad, 1946, iss. 1, pp. 283. 